はスタシオの残響音を無相関に近い形で収音する方法， 直接音信号を 2 分岐してそれぞれ独立の残響付加装置に 加えて無相関の残響信号を得る方法などが利用される. なお，広い間隔を㧊いたマイクロホンで収音すると，直 接音信号にあ大きいチャネル間位相差が導入されて定位 が不明瞭になるが，広がり感形成の目的にはむしろ効果 的である。

一般には，これらの手法で得られた残響信号を直接音 信号に付加して，明瞭な定位感之同時に広がり感を付与 する。しかし，個々の音像定位より広がりを重視する制 作意図であれば，主マイクロホン自体をこの種の方法で 設置したり，あるいは収音された信号に積極的にチャネ ル間位相差を付加する方法むとられる。極端な例は，モ ノホニック信号からステレオ信号を形成し，あるいは 2 チャネル信号から 4 チャネル信号を形成する場合であり いずれも広がり感の形成を目的とした位相差または時間 差の付与が中心的手法として利用されている.

\section{6.むす び}

音声調整技術は古い歴史をもち，経験的知識の集穦に はきわめて豊富なものがあるが, この内容について必ず しも充分な整理が行なわれているとはいえない，番組の 質的向上あるいは，煩雑な調整操作の合理化のためにも 既存の知識の物理的および心理的根拠を明らかにし，体 系化を行なうことがとくに望まれる。

テレビ音声の問題についてみると，彷来音声は一般に 従として扱われ，映像の存在による番組制作上の制約を いかにして克服し, 収音, 調整を行なうかという点に主眼 が扔かれていたといえる。しかし，乙のような消極的態
度のみでなく，音声の表現をさらに広げる手段として， 映像による効果を積極的に利用する方向の研究屯必要で あろう。よよりテレビ番組一般にこのような考え方を 適用するととは無理であり，またその必要性む少ない. しかし，たとえばテレビ音声多重方式に拉けるステレオ 放送は，乙の種の問題を扱うのにまさに適した場といえ よう。この方面で，音声と映像を有機的に結合し相乗的 効果をあげうるような番組制作手法に関して，積極的な 開発が行なわれるととを期待したい.

(昭和 45 年 12 月 25 日受付)

\section{〔参考 文 献〕}

1) J.D. Griffiths: Optimum Linear Filter for Speech Transmission, JASA, 43, 1 (1968) 81-86

2) J. Blauert: Ein neuartiges Präsenzfilter, Fernseh -u. Kinotechnik, 3 (1970) 75-78

3) J. Blauert: Sound Localization in the Median Plane, Acustica, 22, 4 (1969/1970) 205-213

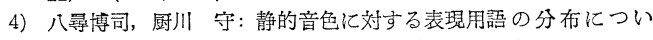
て, 音蠁学会講演論文集, 1967 年 11 月, 393-394

5) 守田 栄: 騒音と騒音防止, オーム社 (1967) 178

6) 柴田光之: 番組音の平均の音の大きさと VU 計による音量レべ ル, NHK技術研究，22，5（1970）433-439

7）江原史郎：番組音のレベル分布， NHK技研月報，9，4（1966) 150-155

8) 山本照二, 永田 穂: 音楽スタジオの収音位置における音響特 性，NHK技術研究，22，6 (1970) 475-489

9）永田 穂：最近の建築音響の進歩， NHK技研月報，13，8（1970） 358-374

10）山本照二，受聴音および維音音圧レベルが残㗽感に及汸す影響， 音響学会講演論文集, 1968 年 11 月, 111-112

11) 氏原淳一：電子式残響合成装置，NHK技研月報，11，12(1968) $584-588$

12）吉田登美男，岩崎俊一，永井健三：立体音の本質は何吕，音響誌， 16, 4 (1960) 249-257

13）牧田康雄：ステレオ音響の基礎的諸問題，NHK技研月報，6，10 (1963) $483-489$

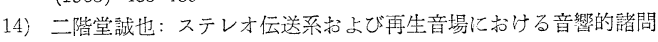
題，放送技術(䧗增)，1967 年 11 月，219-228

\title{
4-2 スタ ジオ収音
}

\section{1. まえがき}

テレビに拉ける情報は音声と映像とから成り，したが って，テレビに预ける番組制作のための収音技術には独 特のむのがある，それは映像と共存するという点ですで にラジオに扮ける収音とは異なり，ドラマに掠いては， 映画と完成作品が類似しているが，制作時の 1 シュート あるいは 1 ブロックの長さが，テレビ創生期には生放送 のみであったことは別にしてあ1本撮りが多い状態であ

\footnotetext{
"2. Studio Prgramming" by Kiyomi Tizuka (Tokyo Broadcasting System Inc., Tokyo)
}

\section{TBS 飯 塚 清 美}

った。

VTR とその編集技術が開発されて，ブロックに分割 して収録するブロック撮りが一般的となり，制作状態が 映画と似て来たが，しかしながら映画においてはあくま でもアフレコが主体であるし，一度に収録する長さむ， 映画が 1 カット撮りが主流であるのに対して，テレビに 怙ける1ブロックの中に含まれるカット数が非常に多い という点, さらに特にテレビは複数台数のカメラを同時 に駆使して番組を制作しているという点で，はるかに複 雑な制作状態にある.

なお，以下は収音技術上の特色には直接関係はないが 
番組を視聴者が視聴する状態もテレビは独自のあのをあ っていて，制作技術者はての点を忘れてはならない.す なわち，テレビは当然のことながら普通の家庭内で環境 音や生活行動音が雑音として存在しているところで, し かも視聴者に抢ける音声に対する受聴意欲はラジオより む，まして入場料を払って見に行く映画におけるより弱 化している.このような悪条件下に音声を担当する者は, 独特の技術を駆使して明瞭度の高い音を送り視聴者を満 足させなければならない，以上がテレビ収音の特異点で ある。

\section{2. テレビスタジオにおける収音の特徴}

上記したような特異性をもつテレビ音声の収音上の基 本となるのはどのような点であるかといえば,

（a）マイクを視聴者に意識させないよう収音するこ と,

（b）画面に適合した音声を構成するように収音する こと,

となる、マイクロホンを視聴者に意識させない収音は， 単にマイクロホンそのあのを画面内に入れないだけでな く，その影屯入れないよう充分考慮し，また，報道番組 のような広報番組などで，格別にマイクロホンの存在に ついて気をつけなくてもよいように一見考えられる場合 であ, 音声担当者は, その映像について充分考慮してい る.

次に，画面に適合した音声とは，必ずしも画面のサイ ズ，構成に合わせた音声という意味ではない，というの は画面構成自体カット数む多く，いろいろなショットが その中に含まれているので，単に画面に合わせて距離を 付けるということははなはな゙困難であり，あまり有意義 ではないからで，とにかく明瞭度の高い音声を収音する ことを基本にする。 また聴取条件を考えると，視聴者は 特別な視聴環境を作って見ているのではないので，ての ような視聴者が，抵抗なくリアルな音として納得できる ように常識的な音を作り上げて行くべきであると思う.

もちろん軽音楽番組に打いて特定楽器を画面上アップで 撮るときには，音声に抽いてもその楽器の音を充分に浮 き上がらせて収音し，多少音楽的でないようになっても 看過することになる，基本的にはテレビのあつ特徵のひ とつである真実性を視聴状態に㧊いて満足するような収 音を心がけねばならない。

\section{3. テレビスタジオにおいて制作される番組}

テレビスタジオにおいて制作される番組は各種各様で あるが，便宜上次のように大別する。

(1) ドラマ
(2) 音楽番組
(3) ニュース, 教養ものなどの広報番組
(4) 視聴者参加番組

\section{4. ドラマにおける収音}

テレビの音声における収音上の問題のすべてを網羅し て含んでいるのが，ドラマ制作における収音である。ド ラマにおける収音において考えるべきことは，画面と音 声の適合ということであり，乙れは次の点に問題がしぼ られる，第一は画面のオン，オフとは必ずしも関係なく シーンの内容に応じたオン, オフを音声に付加するとい うこと，たとえば比較的小さい部屋の内部に括ける会話 は，画面外であってあオンにするということである，第 二は，番組全体を通してショットに対応して音の距離感 を一定の比にすることで，これは直接音と間接音の比， および音量の大小で定まる。

\section{1 機材とセッティング}

ドラマの収音にスタジオで使用する機材は, 副調室内 設備を別に考えると，マイクロホンとそれを演技者に近 づけるための機材であり，マイクロホンは各局それぞれ に各種使用されているようである。テレビスタジオにお けるドラマ制作時には，各種機材と制作にたずさわる人 達の移動に伴う騒音や，演技に伴うセットのきしみ音な ど不用音が多く, しかも収音距離は, マイクロホン本来 の距離より画面上の制約のため離さざるを得ない.した がって使用するマイクロホンは，

（a）亚面特性がセリフに合ったすなおな特性をむつ とと..

（b）背面感度が低く，その音質は耳につかない特性 をむつとと。

（c）形状，重量とあハンドリングに適すること. などの特質が要求される。ささらに同時に多数本使用する ので特性のばらつきのないマイクロホンが必要になる。 以前は 77-DX が多く使用されていたが，激しい使用で リボンが変質し，その結果特性が変動してトーンの統一 化をはかるのに相当苦労していたが, 最近はコンデンサ マイクロホンが FET の使用で電源自蔵化され, 取扱い が容易になり，特性の変動も少なくなってての悩みは解 消された。一方, テレビスタジオのカラー化に伴い照明 の調光装置が半導体化されたため, 音声に対しての電磁 障害がクローズアップされるようになってきたが，ちょ うど都合の良いことにコンデンサマイクロホンのほうが 電磁形のマイクロホンより障害を受けにくいので, 現在 はコンデンサマイクロホンをメインに使用している.

その他に，仕込みマイクロホン，あるいはどうしても 接近して収音できないときのための超指向性マイクロホ 
ンが使用されている，乙れらの特殊マイクロホンは,メ インマイクロホンと音質が同一になるようにという点が 選択の第一基準となっている。その他，ワイヤレスマイ クロホンもしばしば使用されている.

マイクロホンを接近させる機材は主にブームであるが ブームには 1 人で操作するマイクドリーと， 2 人で操作 するパラミュレーター（いわゆるブーム）があり, 現在 は主としてドリ一が多く使われている，奥行きのあるセ ットで, しかもカメラ配置などの制約でドリーではカバ 一できない所は, パラミュレーターでマイクロホンを操 作している. パラミュレーターは, 前者の性能にさらに アームの伸縮が加味されたものであるが，行動の機敏性 においては前者がすぐれている。

以上の他，特殊な場合は手持ち棒によるマイクロホン 支持, また超小形マイクロホンをセットの一部に仕込ん だり，吊り紐によりセット内に吊り込んだりする“仕込 みマイクロホン”あ用いられ，仕込みマイクロホンの特 殊な場合として, 演技者の身体にワイヤレスマイクロホ ンをセットすることあある。

\section{2 ドリーによる収音}

テレビドラマの音声収音は，大部分がマイクドリーに より行なわれており，ラジオにおける収音とはこの点で 明確に区別される，乙の収音における第一の目的は，マ イクロホンを最良の収音位置にセットすることである.

一方, 演技者は静止しているのでなく番組の中で生きた 素材として絶えず行動し，会話を行なうのであるから， これに対しマイクドリーマンは上下, 前後, 左右と全空 間にわたり適当にマイクロホンを移動し，なお同時にマ イクロホン自体を回転しながら向きを変えて演技者を追 わねばならない. しかもマイクドリーマンは, そのとき どきの画面サイズ，照明内容を充分に理解し，映像を損 なわないように操作しなくてはならないため, 前もって ミクサーとは充分打合せ，ミクサーの意図を理解し，自 身の音響知識を利用して作業すべきである。、イクロホ ンの音源に対する角度は, 人の場合, 垂直面内の俯角が 大きくなるほど高域が減衰し, 距離が離れるほど明瞭度 が低下する。

\section{3 ミクシング}

マイクドリーマンの努力により，あるいはまた適当に 仕込まれたマイクロホンにより収音された音声を，ミク サーが画面にマッチした音になるようミクシングする. ミクシングに際しては, カメリ八(カメラリハーサル), ランスルー（最終リハーサル）時に細かい点まで充分に 解決しておくことがミクサーの責任である。たとえば， 本番前に急に演技者がタンスの引き出しを引くアクショ ンが追加され，引きながら会話を収録したととろ，たま
たまその引出しが空であったため空洞の影響で音質が変 化したり，アクションのちょっとした変化のため 2 本の マイクロホンの“乗り代り”のきっかけを間違えるとと などのないようにしなくてはならない.

最近は，番組の大部分が VTR によるパッケージであ りそのスタジオに抽収録は分割方式，いわゆるブロ ック撮りになっている。したがってドラマ制作に拈いて は効果音や音楽をミックスする音声完全パッケージ化作 業が VTR テープ編集後にほとんど行なわれる。

その方法には MAVTR 方式, 関西テレビ方式, TSL 方式等があるが，TBSにおいては前に民放連技術報告会 で発表した TSL 方式を使用している，TSL 作業に入 る前にディレクターを初め音声関係者は編集後のプレビ ューを行ない, 充分に音声に関する打合せを行なって素 材制作に入る，番組内の音楽録音もこの時点で行なわれ るが，劇音楽の録音はすべてオリシナルなので，ミクサ 一のミクシングでどのようにもできるので, 演出者拉よ び作曲者との話し合いが特に必要である。このようにし て, 効果音, 劇音楽がそろうと音声完全パッケージ化作 業に入り，ドラマが完成する.

なお，スタジオでの VTR 収録時のブロック数は最近 非常に多くなり，60 分番組で 40 ブロック以上になるて とあある.すなわち，1ブロックの長さが 1 分前後とな るわけであり, このような場合, 編集後の音洩れが問題 となってくる. この問題解決のため, ブロック数の多い 場合は 0.6 秒遅延用テープレコーダーを通して VTR に 収録している。なおこの際，正常音をリファレンス用に VTR のキュートラックに録音する. この場合は VTR の編集が画面つなぎで自由にできる、編集後の作業の音 声完全パッケージ化作業の入れ込み時に音声部のみ 0.6 秒先行させ,さらにキュートラックのリファレンス音声 と照合しながらリップシンクを行なう。

\section{5. 音楽番組における収音}

一般にテレビ局におけるスタジオは，音楽番組専用と いうことは少なく，多目的スタジオとして建設すること が多いが, その際, スタジオの残響時間は前に述べたよう にスタジオに制作時に存在する不用音の影響を少なくす るため，またドラマを制作できるようにということもあ って, 多面ホリゾントであるがための困難をのり越えて 可能な限り短くしているのが現状であろうと思われる. したがって，とのようなスタジオで音楽番組を収音する と残響感が不足するので, 残響付加は収音上不可欠とな っている. 残響付加装置としては一般に, エコールーム， 鉄板エコ一等がある.

純音楽においては伝統的な演奏形式が完成されている 
ため，テレビスタジオに扔いても演奏会と同様な配置に なり，また演奏されているその生の場に扔ける音が完成 された音であるから，カメラのショットにマッチさせて アップに撮られた楽器の音を際立たさせて収録すること は好ましくない．会場の奥から美しい残響を伴って聞え てくる楽器の演奏者をバストショットで撮るようなとと は，映像と音声の間の違和感を生じさせるととになる。 これはミクサーに責任があるのではなく，画面構成の面 において解決すべきであり，純音楽においては完成され た生の音をそのまま収録すべきであろう。また音楽，歌 謡曲等に㧍的る音声の取扱いは次のようになる。

(a) 同時生演奏

(b) 楽団演奏のみプレレコ

(c) 完全プレレコ

同時生演奏とは，いいかえると生演奏を画，音とも同 時に収録または放送するてとである，ての場合はセット デザインに関して，打合せに扔いて充分意見を述べて， 都合の良いマイクアレンジができるようにする。 それで あ画面構成上思うようにならないととああって, その結 果, マイクロホンの本数が増大する場合がある.

最近では 1 番組中の楽団数が小編成も含めて 3 つにな ることも多く, マイクロホン使用数は 20 本以上になる. このような際には, 楽器群, あるいはグループでとに回 路をまとめてミクシングしやすいようにしている，また ときには， 2 人のミクサーで手分けしてダブルミクシン グを行なうととあある.

楽器演奏のみプレレコする場合には, 歌手の声をミッ クスした時点で最終的にミクシングが評価されるので, 楽器音のプレレコ時におけるバランス, 特にメロディー 楽器群とリズム楽器群のバランスは, 仕上りを充分予想 して録音する必要がある。乙の録音時に 2 チャネルある いは 4 チャネルの録音機を使用し, 楽器群を適当なパー 卜別にした録音を行なえば，番組制作時のミクシングで きめの細かい音作りが可能婂るる。 この場合, 歌手用マ イクロホンは手持ちマイクロホン, 特にワイヤレスマイ クロホンが多く使用される。 あち万ん, 前述の場合であ 歌手用マイクロホンとしてスタンドマイクロホンによら ず手持ちマイクロホンによることあある.

歌手用としてワイヤレスマイクロホンを使用するの は, 歌手がセット内を自由に動け, 画面構成の自由度が はるかに増大するからで, 演出側から多く要求される。 しかし，ワイヤレスマイクロホンにあいろいろ考えねば ならない問題(たとえば,デッドポイント，妨害電波等)が あり，まだ完全に安心して使用できる状態ではないが, 受信アンテナの設置法, ダイバーシティー受信, 送信出 力の增強等々の手段をつくして, より安心して使えるよ
うに工夫しているのが現状である，完全プレレコによる 場合は，特記するようなととはないが，自局で同時に収 録した素材だけでなく，別々なときに別な所で収録した 素材を使用することがあるため, 番組全体を通しての音 質の統一をはかるように配慮せ秋ばならない．

音楽番組に使用するマイクロホンはラジオ用と大差な いが，歌手用マイクロホンでは音質などの特性はもちろ ん, 形状についても，画面効果を充分に考えて選定され る。また音楽番組においては，曲の間にコントなどを挿 入するが，乙れは映像的にはあまり細かいカメラ割りあ なく,グループショットに近い画面が多いので, 収音マ イクロホンとしては離れた収音位置で使用できる超指向 性マイクロホンを使用すると便利である。

\section{6. 報道，教養など広報番組の収音}

この種の番組においては，特に明瞭度を上げるように 心がけるととが必要で, マイクロホンむ画面内に入れて 良い場合が多いが，ちょっと工夫すれば小道具の陰にか くせたりするので, コードの整理など, やはりテレビで あるがための注意は払わなければならない。

円卓を囲んでの座談む多く, 収音し難いセットあある が，超小形マイクロホンを吊るしたりして収音してい る. 声量の少ない人む多く, 音量のバランス, 不用音の 除去が必要であるが，円卓座談用には特別に開発された ドーナツ状指向特性をあつマイクあある。また視聴者な ぞ，ある種の人達のグループを参加させ，インタビュー を行ないながら進行して行く番組ああるが, インタビュ ーマイクロホンが複数本になる場合には，その使い分け などに注意すべきである。

\section{7. 視聴者参加番組における収音}

この種の番組に打ける収音上の問題点は, 場内拡声, いわゆる PA と場内ノイズの収音である。テレビスタジ オは公開ホールと異なり，そのつど客席をセットするの で, その位置む一定していない. 一方, テレビスタジオに おける既設のPA 装置は，一般にスタジオ全体に一定レ ベルで送り出すようになっているため，乙のような装置 で客席に充分なレベルで聞かせようとすると, ハウリン グを起こす。このため客席に多数のスピーカーをセット してグループに分け，その音量をコントロールできるよ うにした小区分カバーによる PA 装置を使用している.

トーンゾイレ形のスピーカーの使用む考えられるが, テレビスタジオの音響的条件などを考えると充分な効果 を発揮させるのはむりであると思われる。

場内ノイズの収音は, 単一指向性マイクロホンを客席 上に何本か適当に吊るし，乙れす小区分カバー方式で収 
音し，番組効果をむり上げるよう努力している.

以上，テレビスタジオにおける各種番組別の収音につ いて概略を述べたが，参考までに現在多く使用されてい る代表的なマイクロホン名を記す。

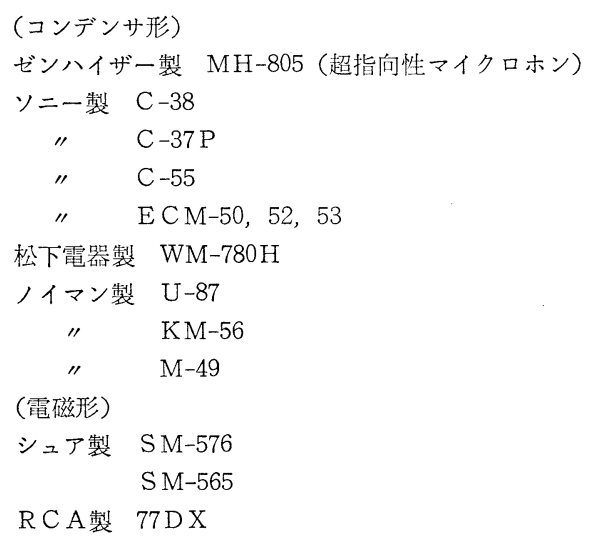

\section{8.むすび}

今後のテレビにおける制作々業は，作品の品質向上に
寄与する面とともに，作業を合理的に容易にする面に技 術革新の成果を充分に利用して行かなければならない. しかも，乙れは音声面における機材の進歩のみならず, 映像，照明の機材と制作方式の進歩が音声作業の向上に 役立つはずである。一例をあげると，ワイヤレス方式の カメラはスタジオ内の不用音の軽減に役立つとともに, ブームの移動をあ容易にする，一方，音声機材としては ワイヤレスマイクロホンがケーブル付きマイクロホンと まったく同等に使用可能となり，さらに超小形化するな らば作業の安定化に役立つであろう。調整卓においても 記憶装置付きのビデオ・オーディオスイッチャーの利用 などが期待される。

さらに進んでは，開発されつつある立体映像と対応す るための完全な立体音響のテレビに打ける収音再生方式 の確立も考えなければならない，われわれは常に新しい 技術を駆使しながら，作品の向上を心がけねばならない と思っている.

(昭和 45 年 12 月 11 日受付)

\section{4-3 局 外収 音}

\section{1. え がき}

中継番組の特徵は，局側の作業態勢が受身であること が多いととである。すなわち，スタジオ番組ではディレ クターの演出意図にそって番組を作っていく積極的な意 味をもっているが, 中継番組では演劇，スポーツ，事故 現場など，テレビに関係ないところで事実が進行してい る中にテレビ局が入っていって，視聴者にこの事実をい かに忠実にテレビを通して再現するかが大きなテーマと なる。公開番組のような例外はあるが，このととがスタ ジオと中継の異なる点である，技術的な観点からいえば 音に対する基本は，スタジオも中継も何ら変わらないが 中継番組をミクシングするに当ってまず頭に入れておか ねばならないことである。

中継現場には音響設備のある条件の良い所屯あれば, まったく設備のない所むあり，あらゆる音響条件の場所 でミクシングしなければならない，また，マイクロホン が 1 〜 本ですむ番組むあれば，50本以上使用する番組 あある. また, 台風の中継のように風雨の中で番組制作

"3. On the Spot Programming" by Masataka_Nagata (Fuji Television Corp., Tokyo)
フジテレビ 永田正孝

するときむあれば，屋内中継のように気象条件にまった く左右されない状態で番組制作するときすある，てのよ うに受身である以上, いろいろな条件, 制約の中で番組. 制作するわけで，てれらの状態を的確に判断し，敏速に 処理しなければならない.

\section{2. 屋内 中 継}

\section{1 劇場中継}

劇場中継は歌舞伎，新派，新劇など芝居の舞台中継之 レビューなどショウの公演 (ホール, 公会堂, 体育館等: を利用したものを含む）の中継が代表的である.

\section{(1) 舞台中継}

舞台中継で大切なととは，テレビの視聴者を観客席に 引き入れるように心がけることである。 そのために適当 な音の広がり，観客のリアクションが重要となる。また 舞台中継で特に気をつけなければならないことは，マイ クロホンを目立たしてはいけないととで，観客は芝居を 見に来ているのであって，その芝居を妨げるようなマイ クセットは絶対にさけなければならない，その点ショウ の公演は，マイクロホンがステージにあっても不自然で はないし，ミクサーの希望もある程度受け入れられる。 